\title{
Masaj ve Toparlanmaya Etkileri
}

\author{
Ersan KARA $^{1}$ iD \\ Gülşah ÜNVER² \\ ${ }^{1}$ Alanya Alaaddin Keykubat Üniversitesi, Spor Bilimleri Fakültesi, ALANYA \\ ${ }^{2}$ Kahramanmaraş Sütçü İmam Üniversitesi, Fizyoterapi ve Rehabilitasyon Bölümü, KAHRAMANMARAŞ
}

DOI: 10.31680/gaunjss.518840

Orijinal Makale / Original Article

Geliş Tarihi / Received: 28.01.2019

Kabul Tarihi / Accepted: 03.03.2019

Yayın Tarihi / Published: 22.03.2019

Öz

Toparlanma, spora özgü faaliyetler sonrasında organizmanın istirahat halindeki değerlere dönme süreci olarak değerlendirilmektedir. Günümüzde pek çok spor dalında, sporcular yoğun ve yorucu antrenman ve müsabakalara maruz kalmaktadırlar. Antrenman ve toparlanma ilişkisi doğru bir şekilde ayarlanmadığında, sporcuların performansında belirgin düzeyde düşüşler meydana gelmekte, sürantrene durumu oluşarak, sporcuların antrenmanlardan ve/veya müsabakalardan belirli bir süre uzak kalmasına yol açmakta ve hatta sporcunun sporu bırakmasıyla sonuçlanabilmektedir. Yüklenme ve uyum sürecinin değerlendirilmesinde yüklenmenin öğeleri ile dinlenmenin bir arada değerlendirilmesi önemlidir. Toparlanma yöntemleri ne kadar uygun ve doğru yapılırsa, sporcuların performansları o oranda yüksek olur, sakatlanma riski ortadan kalkar ve spordan uzak kalma süreleri kısalır. Doğru ve uygun toparlanma yönteminin uygulanması, yüklenme ile toparlanma arasındaki dengenin sağlanmasına dair bilincin yerleşmesi ve uygulamaya geçirilmesi hem sporcunun sağlığı hem de optimum performansa erişilmesi yönünden oldukça önemlidir. Tam toparlanma gerçekleşmeden yapılan yüklenmeler sakatlanmalara ve performans düşüklüklerine neden olabilmektedir. Yapılan çalışmalar incelendiğinde toparlanmada etkili olan çok sayıda yöntem bulunmaktadır. Bu yöntemler arasında en yaygın kullanılanlardan biride masajdır. Masaj, yumuşak dokulara uygulanan, organizma üzerine pek çok etkileri olan manipülatif tekniklerdir. Masajın, özellikle lokomotor sistem ve kardiyovasküler sistem başta olmak üzere organizmayı oluşturan diğer sistemler ve yapılar üzerine de birçok fizyolojik, mekanik ve psikolojik etkileri mevcuttur. Bu çalışmanın amacı, literatürde masaj ile masajın toparlanmaya olan etkilerinin değerlendirilmesiyle ilgili yapılmış çalışmaları inceleyerek bu konuyla ilgili bundan sonra yapılacak çalışmalara kaynak oluşturmaktır.

Anahtar Kelimeler: Masaj, toparlanma, spor.

\section{Massage and Effects on Recovery}

\begin{abstract}
The recovery is considered as the process of returning the organism to resting values after sports-specific activities.Nowadays, in many sports branches, athletes may have to do intensive training. Significant reductions in the performance of athletes may occur when the training and recovery relationship is not properly adjusted. In the case of a sedation, athletes may be away from training and / or competitions for a certain period of time and may even leave the athlete's sport.In the evaluation of the loading and adaptation process, both the elements of the loading and the outcome of resting stand out. The more accurate the recovery can be, the better the quality results and the higher level achievements.Applying the correct and appropriate recovery method, establishing the balance between the loading and recovery, and implementing it is very important both for the health of the athlete and for reaching the optimum performance. Loads without complete recovery can lead to injuries and performance degradation.When the studies are examined, there are many methods that are effective in recovery. One of the most widely used methods is massage. Massage is the manipulative techniques that are applied to soft tissues and have many effects on the organism. Massages, especially the locomotor system and cardiovascular system, as well as other systems and structures that make up the organism, there are many physiological, mechanical and psychological effects. The aim of this study is to examine the studies on the effects of massage and massage on recovery in the literature.
\end{abstract}

Keywords: Massage, recovery, sports.

\footnotetext{
${ }^{1}$ Sorumlu Yazar: Ersan KARA
}

E-mail: ersan.kara@usak.edu.tr 
Kara, E., Ünver, G. (2019). Masaj ve Toparlanmaya Etkileri. Gaziantep Üniversitesi Spor Bilimleri Dergisi, 4(1), 28-49.

\section{Giriş}

\section{Masajın Tanımı ve Kapsamı}

Masajın kelime anlamı; Yunancada yoğurma anlamında kullanılan "massein" kelimesi ile Arapçada dokunma anlamında kullanılan "mass" kelimelerinden köken alır. Masaj, vücuttaki yumuşak dokulara çeşitli manipülasyon uygulamaları yapılması esasına dayanan, organizmada fizyolojik ve/veya psikolojik etkiler meydana getiren mekanik uyarıcılar olarak tanımlanabilir (Kanbir, 2008). Masajdaki manipülatif uygulamalar kompresyon, friksiyon, vibrasyon, stroking, perküsyon, kneading, germe gibi uygulamaları kapsar ve mekanik uyarı oluşturan bu tekniklerin tek tek ya da kombine edilerek uygulanmasından oluşan masaj, kısaca sağlığı koruyucu ve tedavi edici manuel yöntemlerdir.

Masajın vücutta uygulanabileceği başlıca yumuşak doku alanlarını deri, kaslar, fasia ve ligamentler oluşturur (Yüksel, 2007). Masaj uygulamaları, esas olarak kan ve lenf dolaşımına yardım etmek ve kaslardaki spazmı azaltmak amaçlarına yönelik olarak uygulanan, geleneksel doğal tedavi yöntemleridir (Yı et al., 2008).

\section{Masajın Tarihçesi}

İnsan vücuduna ellerle yapılan sıvazlama, dokunma gibi el değmelerinin doğal tedavi yöntemi olarak uygulanmasının geçmişi çok eski çağlara dayanmaktadır. Yaklaşık beş bin yıllık geçmişi olan masaj uygulamalarının, tam olarak bugünkü uygulanış şekli ve amacı için olmasa da farklı amaçlar ile Çin, Greek, Hint ve Mısırlılar tarafından kullanıldığı bilinmektedir. Masajın sağlık amaçlı kullanımı ise yaklaşık olarak MÖ 3000 yıllarına dayanmaktadır. Çünkü Çin'de bu yıllara ait belgelerde masajdan bahsedilmiştir. Özellikle Hindistan'da masaj uygulamaları eterik yağlar ile uygulanmış ve bu uygulama Ayurveda tıbbının tedavi yöntemleri arasında oldukça önemli olmuştur (Kanbir, 2008; Sarıkaya 2002).

14. yy' ın sonlarına doğru Rönesans'la beraber masaj uygulamaları yaygınlaşmıştır. Masaj uygulamaları, 17. yy'da P. H. Ling'in Stockholm'da, Metzger'in ise Amsterdam'daki çalışmalarının sonucunda uygulama sahalarında daha fazla yer almaya başlamış ve isim olarak da "İsveç Masajı" olarak kullanıımıştır. 1893 yılında ise A. Hoffa, Stutgart'da yayınlamış olduğu eserinde İsveç Masaj'ına fazlaca yer vermiş, masajdaki manipülasyonları; öfloraj (sıvazlama), friksiyon (dairesel hareketler), petrisaj (yoğurma), tapotmen (vurma) ve vibrasyon (titreştirme) olarak beş temel manipülatif teknik olarak gruplandırmıştır. Bu manipülatif tekniklerin günümüzde uygulaması hâlâ devam etmektedir. A.Hoffa, ilgili kaynakta vücudu 
Kara, E., Ünver, G. (2019). Masaj ve Toparlanmaya Etkileri. Gaziantep Üniversitesi Spor Bilimleri Dergisi, 4(1), 28-49.

topoğrafik olarak kısımlara ayırmış, masaj uygulamalarının yapılışını göstermiş ve eserinde masajın sinir sistemine yönelik etkilerine de yer vermiştir (Tuna,1997; Kanbir, 1998).

İsveç Masajının yanı sıra farklı özel masaj yöntemleri de geliştirilmiştir. Bunların arasında en çok ilgi duyulanlar; Emil Vodder'in geliştirmiş olduğu "Lenf Drenajı Masajı", Glaser ve Kibler'in geliştirmiş oldukları "Segmental Masaj", fizyoterapist Elisabeth Dicke'nin geliştirmiş olduğu "Konnektif Doku Masajı (KDM)", Ruhmann'ın geliştirmiş olduğu "Sinir Noktaları Masajı" gibi özel masaj teknikleridir. Ancak her ne kadar bu masaj teknikleri ortaya konulmuş olsa da, tüm bu özel masajlar İsveç Masajı kadar genel ve yaygın kullanım alanı bulamayarak daha kısıtı kalmıştır. Günümüzde bu yöntemler arasında yaygın bir şekilde kullanılan masaj yöntemi ise manipülatif tekniklerin tek tek veya çeşitli kombinasyonlarıyla uygulandığı İsveç Masajı'dır (Tuna, 1997).

\section{Masajın Etkileri ve Etki Mekanizmaları}

Masaj, vücuda yapılan mekanik uyarılara cevap şeklinde gerçekleşen bir dizi reaksiyon meydana getirir. Bu reaksiyonlar uygulanan her teknik için farklı düzeylerde gerçekleşir. Masaj; deri, deri altı dokular ve kaslarda lokal bir şekilde uygulanır ve refleks yollarla iç organlara kadar etkisini aktaracak düzeyde de etkiye sahiptir. Masajın, özellikle lokomotor sistem ve kardiyovasküler sistem başta olmak üzere organizmayı oluşturan diğer sistemler ve yapılarda da fizyolojik, mekanik ve psikolojik etkileri mevcuttur (Tuna, 1997).

Masajın etkileri arasında; hücrelerin rejenerasyonunu sağlama, hücrelerin beslenmesini arttırma, üre ve diğer atık maddelerin atıımını kolaylaştırma, derinin esnekliğini arttırma, sebum üretimini arttırma, enfeksiyonlara karşı direnci artırma, fibrosis ve skar doku oluşumunu engelleme, oluşmuş skar dokuların gevşemesini sağlama, mobilizasyonu artırma, derideki ve deri altındaki yapışıklıkları giderme, solunum yolları ve solunum organındaki sekresyonu mobilize etme, abdominal distonsiyonu aza indirme ve/veya önleme, peristaltik hareketleri arttırarak konstipasyon, kolik gibi yakınmaları azaltma ve/veya önleme, parasempatik sinir sisteminin aktivitesini artırma, sindirim işlevlerini daha kolay gerçekleştirilebilir hale getirme, yoğun şiddetteki kas aktivitesi neticesinde oluşarak kasta biriken toksinlerin ve diğer atık ürünlerin uzaklaştııımasını kolaylaştırma, gerek lokal gerek genel kan, venöz, lenf akımı artırma, toksik maddelerin lenf ve venöz kan dolaşımına geçişini hızlandırma, kasların beslenmesine yönelik olarak daha fazla besin ve oksijen 
Kara, E., Ünver, G. (2019). Masaj ve Toparlanmaya Etkileri. Gaziantep Üniversitesi Spor Bilimleri Dergisi, 4(1), 28-49.

alınmasını sağlama, genellikle ağır antrenmanlar sonucu meydana gelen kas yorgunluğunu azaltma, yine spor aktiviteleri sonrasında oluşan kas ağrısını azaltıp kas hasarının önüne geçme, toparlanma sürecini hızlandırma, difüzyon ve oksidasyonu arttırma, biriken laktat'ın kastan daha çabuk ve kolay bir şekilde uzaklaştııııasını sağlama, kasın kan hacmini attırma, sedatif etki oluşturma, gevşemeyi sağlama, endokrin sistem ve otonom sinir sistemi üzerinde refleks etkiler oluşturma, sempatik inhibisyona yardım etme, H-refleks amplitüdünü düşürerek motor nöron eksitabilitesini geçici olarak azaltma, gevşeme oluşturarak kalp hızını azaltma, kapillerlerin dilatasyonuna bağlı olarak kan basıncının geçici şekilde azaltımasına yardım etme, endorfinlerin salınımını kolaylaştırarak ağrıın inhibisyonuna yardım etme, iskemiyi azaltma, akciğer hacim ve kapasitelerini geliştirme, solunum kaslarındaki gerginliği azaltarak solunumsal fonksiyonların kalitesini arttırma, sempatik sinir sistemini uyararak solunum hızını yavaşlatma, dolaşımsal etkilerinin katkısıyla idrar atıımını kolaylaştırma, stres ve anksiyete kontrolü sağlama, iyilik hali oluşturma, özgüven duygusunu geliştirme, vücut imajının ve görsel algının gelişimine katkı sağlama, emosyonel travmalara daha kolay karşı koyabilme ve başa çıkabilmeyi hızlandırma, venöz basıncı azaltarak arterial dolaşımın artmasına yardım etme, venöstaz'ı önleme, antikoagülan etkisi meydana getirme, hemodilüasyona yol açma, lenfatik direnajı arttırıp artık ürünleri uzaklaştırarak ödemi azaltma, immün sistemi güçlendirme, stres hormonlarının özellikle katekolominlerin salgı seviyesini azaltma, serotonin hormon salgı düzeyini artırma, immün sistemi güçlendirme, motor gelişmeyi ve koordinasyonu sağlama, uyku bütünlüğü ve derinliğini sağlayarak uyku kalitesini arttırma, konjesyonu azaltma, hastalıkları tedavi etme, bütünsel olarak değerlendirildiğinde de genel sağıı̆ı (fiziksel, psikolojik, ruhsal, sosyal açıdan) koruma yer alır (Yüksel, 2007).

Yine masajın etkileri arasında adezyonları açma, vücut sıvılarını daha fazla mobilize etme, spazm olan kasların gevşemesini sağlama, histamin ve asetilkolin gibi bazı hormonal salgıların salınım seviyesini artırarak vazodilatasyon oluşturma, kasların tonusunu düzenlemeye yönelik olarak hipotonik kaslarda tonus artışı sağlarken, hipertonik kasların da tonusunu azaltma, reaktif hiperemi sağlama, kapiller duvarların geçirgenliğini artırma, iç organlarda uyarıcı etki meydana getirme, dolaşımı artırmasıyla kalbin pompalama gücünü artırma, vazodilatasyonun oluşmasıyla basının olduğu kısımlarda da kan akımını arttırma, dekübit ülserinin oluşmasını engelleme ve/veya seviyesini hafifletmeyi sağlama, bölgede biriken 
Kara, E., Ünver, G. (2019). Masaj ve Toparlanmaya Etkileri. Gaziantep Üniversitesi Spor Bilimleri Dergisi, 4(1), 28-49.

metabolitlerin uzaklaştııımasını kolaylaştırma, derideki dokunma reseptörlerini uyarma da bulunur (Atchisonet al., 1996; Blanc-Louvryet al.; 2002, Dicle, 2007; Kolcaba et al., 2006; Myers et al. 2008; Karadeniz, 1997; Jiang and Qin 2008; Kwekkeboom and Gretarsdottir, 2006).

Araştırmacıların görüşleri doğrultusunda bakıldığında genel kanı; masajın sağlığın korunmasında, sağlıkla ilgili sorunların aza indirgenmesinde gerekli olduğu ve fayda sağladığı yönündedir (Uzuner, 1998; Touch Research Institute, 2009; Field, 2000; Lindrea and Stainton 2000).

Masajın öncelikli etkisinin kan ve lenf dolaşımını arttırma üzerine olduğu düşünülmektedir. Kan ve lenf dolaşımının artması, ikincil mekanizmalar olarak görebileceğimiz birtakım değişimler sağlamaktadır. Masajla dokuları besleyen maddelerin hareketlerinin artması ve kan damarlarında da mekanik etkinin oluşması gibi değişimler olur. Bu doku stimülasyonları da otonomik sinir sisteminin refleks cevabı olup, bu sayede kan ve lenf dolaşımı artışı sağlanmış olur (Yates, 2004).

Masajın içerisindeki manipülatif uygulamaların hemen hemen hepsi kan akımını artırmakla birlikte, kan akımını masaj teknikleri arasındaki bilhassa yüzeysel olarak uygulanan friksiyon, stroking, kneading ve ritmik kompresyon uygulamaları daha çok arttırmaktadır. Bu teknikler kendi aralarında ikili ya da çoklu olacak şekilde kombine olarak uygulandığında ise daha iyi sonuçlar elde edilmektedir. Stroke uygulamaları da üst ve alt ekstremitede yapılacaksa, uygulamanın distalden proksimale doğru uygulanması dolaşım için daha etkili olacaktır. Masajın dolaşıma olan etkisinin daha çok yüzeysel venler üzerinde olduğu düşünülmekte olup, pek çok araştırmanın sonuçları masaj uygulaması esnasında lenf akışının daha fazla arttığını göstermiştir (Yüksel, 2007; Yates, 2004).

Masajın bilimsel ve klinik olarak kesinleşmiş en olumlu etkisi, kan ve lenf dolaşımının üzerine olan etkisidir. Kalp ya da büyük lenf damarları ve düğümleri yönünde yapılan yumuşak, sakin ve derin etkili masaj manipülasyonlarıyla arteriyel ve venöz kan dolaşımıyla beraber lenf akışı uyarılarak aktive edilir. Kalp yönünde yapılan masajla, venöz akım daha da hızlandırılarak, vurum sayısında artış olacak, kan akım hacmi büyüyecek dolayısıyla daha fazla kanın çevreye pompalanması sağlanacaktır. Otonom sinir sisteminin uyarılmasıyla, damar sisteminde refleksif bir şekilde vazodilatasyon meydana gelir. Kaslardaki kan akımında deriye benzer biçimde refleksif olarak da artış gözlenir (Tuna,1997). 
Kara, E., Ünver, G. (2019). Masaj ve Toparlanmaya Etkileri. Gaziantep Üniversitesi Spor Bilimleri Dergisi, $4(1), 28-49$.

Yaygın olarak bilinen bir husus vardır ki; kan akım hızının artışı, kasların laktat difüzyonu ve oksidasyonundaki artış ile ilişkilidir. Masajın oluşturduğu stimülasyonlar, kan akışını hızlandırdığı için kan laktatının daha hızı bir şekilde uzaklaştırımasını sağlamaktadır (Wilmore and Costill, 1994).

Masajın önemli etkilerinden birisi de analjezik etkisidir. Bu etkinin oluşmasının temelinde manipülatif teniklerin sağladığı uyarıların çeşitli mekanizmalara etkisi yatmaktadır. Masajın ağrı-spazm-ağrı döngüsünü kırdığı bilinmektedir. Masaj ile ağrının azalması, masaj uygulamalarıyla periferal dokunma duyusu reseptörlerinin stimülasyonu şeklinde sağlanır. Şöyle ki; kalın liflerin uyarılması ile substansiya jelatinosa'daki inhibitör ara nöronların inhibe edici etkilerinde artış olur. Masajın kalın lifleri uyarması ile ince liflerle (A delta ve C) gelen nosiseptif uyarılar medulla spinalis düzeyine geçemez ve kapı kapanması sonucu ağrı kontrol edilmiş olunur. Kapı kontrol teorisi esasına göre analjezik etkisi sağlanmış olur (Atchison et. al., 1996). Kısacası; A beta lifleri mekanik uyaranlara duyarlıdır. Masaj, mekanik stres üzerinde değiştirici etkiye sahip olduğundan A beta liflerini uyarır. Bu uyarmayla da kapı kontrol mekanizması aktive edilerek ağrının inhibe edilmesi sağlanmış olur (Fernandez-de-las-penas et al.,2006). Öte yandan masajın mekanik etkisinin yanında refleks etkisiyle kas iğciği aktivitesi üzerine inhibitör etki oluşturup geniş çaplı duysal affrentleri uyararak dolaşım ve relaksasyonu arttırır. Bu etkiler sonucunda da analjezik etkiyi sağlamış olur (Torsten, 1997; Melzack and Wall, 1996).

Bazı durumlarda da masaj ağrı giderici etkisini endorfin üretimini kolaylaştırarak sağlamaktadır. Bu yönleriyle düşünüldüğünde masaj yöntemlerinin tedavi için yardımcı modalite olarak kullanılabileceği ve tedavi aşamalarını destekleyebileceği belirtilmektedir (Fritz, 1995). Masaj uygulamaları sonrasında endorfin salınımının artışı ile ağrı eşiğinin yükseldiği belirtilmektedir (Ernst, 1999).

Bu fizyolojik mekanizmaların yanında; masajın bazı hormon düzeylerinde artış sağladığı (özellikle serotonin) bilinmektedir. Hormonal olarak düşünüldüğünde bazı masaj yöntemleri orta şiddette ve kontrollü ağrı oluşturarak opioidlerin ve serotoninin serbestleşmesini aktive ederek, ağrıda inhibisyon sağlamış olur (Edmond, 2006).

Masaj uygulamaları; dolaşımı arttırması ve ağrıyı azaltıcı etkilerinin fizyolojik mekanizmalarıyla beraber kişilerin mental, fiziksel açıdan genel olarak rahatlayarak, kendilerini daha mutlu hissetmesini sağlayan bir yöntem olarak da fonksiyon görmektedir. Masajın etkilerinin mekanizması, masaj sırasındaki affektif ve 
Kara, E., Ünver, G. (2019). Masaj ve Toparlanmaya Etkileri. Gaziantep Üniversitesi Spor Bilimleri Dergisi, 4(1), 28-49.

emosyonel cevapların, limbik yapılarla düzenlenerek sempatik aktivitenin azalmasına yol açması fizyolojik mekanizması ile açıklanabilir (Aourell et al., 2005).

\section{Masaj Çeşitleri}

Masaj kapsamındaki geleneksel manipülasyon tekniklerinin tamamı esasında sezgisel olarak oluşmuştur ve doğal hareketleri içinde barındırır. Masaj çeşitleri arasında kullanımı en fazla olan masaj çeşidi İsveç Masajı'dır. Bu masaj çeşidi Klasik Masaj olarak da bilinmektedir. Klasik Masaj'da 5 temel manipülatif teknik uygulaması bulunmaktadır. Bu tekniksel uygulamaların her birinin özel bir ismi olup, bunlar; öfloraj, petrisaj, friksiyon, tapotmen ve vibrasyon olarak adlandırımaktadır (Fritz, 1995; Kurre, 1997, Beyazova ve Kutsal 2000). Bu teknikler arasında yer alan ve en çok bilineni öfloraj olup, öfloraj, stroking ya da sıvazlama olarak da isimlendirilebilir. Öfloraj, masajın yapıldığı dokunun masaja hazırlanması için uygulanan bir tekniktir. Yumuşak dokuya uygulanan sıvazlama şeklindeki hareketlerden oluşur. Genel itibarıyla öfloraj, masajın başlangıcında ve sonlandırılmasında kullanılır. Daha sonra uygulanacak diğer tekniklere (petrisaj, vibrasyon gibi) kişiyi hazırlamak için önemli bir başlangıç uygulaması olarak bilinir. Amaca göre öflorajın yüzeysel ya da derin olmak üzere iki şekilde uygulaması bulunmaktadır. Yüzeysel öfloraj, geniş yüzeyleri etkileyecek şekilde, parmaklar ve avuç içinin kullanıldığı, yani elin bütününün kullanılarak yapıldığı hafif sıvazlama hareketleri şeklindeki manipülatif uygulamadır. Kas liflerinin yönünde uygulanılır. Hareketler düz, akıcı, ritmiktir. Derin öfloraj ise elin tümü ile önemli miktarda kuvvet uygulanarak yapılır. Derin öfloraj, kas fibrillerinin uzun eksenine paralel yönde ve kasın bütününe olacak şekilde uygulanmalıdır. Her bir hareketin etkisi bir öncekinin üzerine gelecek şekilde organize edilmelidir. Başlangıç noktasına dönerken, ellerin deri ile temasının kesilmemesine ve geri dönerken herhangi bir basınç uygulanmamasına dikkat edilmelidir (Yüksel, 2007; Hazır, 2001).

Bir diğer manipülatif teknik de petrisajdır. Petrisaj, kneading veya yoğurma olarak da adlandırılmaktadır. Bu teknikte uygulama yapılacak yumuşak doku, dairesel veya S harfi oluşturacak şekilde katlanarak sıkıştırılma şeklinde uygulama yapılır. Her bir harekette eller bitişikteki dokuya doğru ilerletilir. Petrisaj özellikle kas spazmının ve fibröz dokuların çözülmesinde, kasların esnetilmesinde etkilidir. Petrisaj aynı zamanda vücut sıvılarının akışını hızlandırır ve dokulardaki ödemin azaltılıp ortadan kaldırılmasına yardımcı olabilir (Yüksel, 2007). 
Kara, E., Ünver, G. (2019). Masaj ve Toparlanmaya Etkileri. Gaziantep Üniversitesi Spor Bilimleri Dergisi, $4(1), 28-49$.

İsveç Masajı'nın içinde bulunan tekniklerden biri de friksiyondur. En eski manipülatif tekniklerden birisidir. Friksiyon daha sıkıkla, deri kan akımını arttırmak ve yüzeysel ısınma sağlayıp doku ısısını arttırmak için kullanıı. Friksiyonun uygulanmasında el doku üzerine yerleştirildikten sonra deri üzerinde hızla ileri-geri doğru hareket ettirilir. Daha çok lokal uygulaması yaygındır. Friksiyonda doğrudan hasarlı doku hedef alınılır.

İsveç Masajı'ndaki bir diğer manipülatif teknik ise tapotmandır. Tapotman perküsyon olarak da isimlendirilebilir. Vurma, çarpma şeklindeki hareketleri içeren bir tekniktir (Hazır, 2001).

Klasik masajın içerisindeki son teknik ise vibrasyon olup, titreşim olarak da adlandırılır ki parmaklar ile elin vücuda temas ettirilmesi sağlanarak ortaya çıkarılan titretme hareketidir. Vibrasyonun uygulaması yeterli şiddet düzeyinde ve sürede yapıldığında bazı refleks fizyolojik etkiler oluşturur (Yüksel, 2007). Vibrasyon, elle yapılmasının yanı sıra vibrasyon üreten makinelerle de yapılmaktadır. Günümüzde masaj etkisi oluşturmak için kullanılan mekanik aletlerin temelinde, vibrasyon etkisi oluşturmak yatmaktadır. Ancak bu aletlerin etkisi daha kısıtlı kalmaktadır. Kısıtlı kalmasının nedeni, dokunmanın yarattığı etkiden yoksun olmasıdır. Ellerle hafif basınç üretilerek yapılan mekanik uyarılar, kasların gevşemesine daha fazla yardımcı olacağından, elle yapılması daha önemlidir. Vibrasyonun basınç etki durumuna göre, etkilediği nöroreseptörler değişir. Daha hafif uygulandığında, yüzeye yakın nöroreseptörler üzerine etkilerini gösterirken, daha yüksek basınçlı vibrasyon ise daha derindeki nöroreseptörlerde uyarı sağlar (Hazır, 2001).

Kullanımdaki yaygınlığı her ne kadar İsveç Masajı kadar olmasa da, kullanımı diğerlerine göre daha yaygın olan diğer iki masaj çeşidi ise Konnektif Doku Masajı ve Lenf Drenaj Masajı'dır. Konnektif Doku Masajı, geleneksel ve alternatif tedavi metotları dahilinde etkileşim sağlayan önemli bir manipulatif tedavi şeklidir. 1929'da Alman fizyoterapist Elisabeth Dicke'nin kendi üzerinde deneme çalışmalarılyla geliştirilmiştir. Konnektif Doku Masajı, konnektif dokulara çekme şeklinde uygulanılır. Oluşan kuvvet ile derideki otonom sinir uçlarının uyarıımasını sağlayan refleks bir terapi şeklidir. Konnektif Doku Masajı'nın etki mekanizması henüz net olarak izah edilememiş olmakla beraber, sempatik ve parasempatik sinir sistemi arasındaki dengeyi sağladığına dair bilgiler mevcuttur (Reed and Held 1988).

Lenf Drenaj Masajı ise bloke olmuş lenf sıvısının serbest akışının sağlanması esasına dayanır. Lenf sisteminin manipule edilmesiyle oluşturulan bir uygulama 
Kara, E., Ünver, G. (2019). Masaj ve Toparlanmaya Etkileri. Gaziantep Üniversitesi Spor Bilimleri Dergisi, 4(1), 28-49.

tekniğidir. Manuel Lenf Drenajı hafif basınç uygulamaları şeklinde yapılır. Basınç, yüzeysel lenf damarlarına uygulanılır. Manuel Lenf Drenajının esas amacı, lenf sıvısının ödemin olduğu bölgeden alınarak vücuttaki diğer bölgelere olan akışııın sağlanmasıdır (Demir, 2008).

\section{Egzersiz Sonrası Toparlanma}

Spor'un, bireyler üzerindeki fiziksel, mental, sosyal ve ruhsal açıdan yararları ve önemi günümüzde insanlar tarafından yaygın bir şekilde kabul görmektedir. Spor'un önemine dair bilinç arttıkça, spor'a olan ilgi ve sportif aktivitelere katılım da her geçen gün artı̧̧ göstermektedir (Harbili, 1998).

Spor, temelinde fiziksel aktivite ve egzersiz olmak üzere pek çok uygulamayı barındıran bir disiplindir. Kişilerin, egzersiz yapmaları sonucunda organizmalarında farklı düzeylerde stressör etki oluşur. Egzersiz ile birtakım fizyolojik değişikliklerin gözlenmesi kaçınılmaz olup, önemli olan egzersizle oluşabilecek değişikliklere karşı homeostaziyi olabildiğince korumayı sağlayabilmektir.

Sporcuların egzersize başlamalarıyla, impuls iletilerinin oluşumunu takiben kaslarda uyarılma, kontraksiyon ve güç oluşur. Bu gücün meydana gelişinde gerekli olan enerjinin sağlanması durumu ise egzersizin şiddeti, süresi gibi faktörlere bağlı olarak değişkenlik gösterir (Harbili, 1998).

Egzersizin başlangıç kısmında, enerji olarak daha çok hali hazırda kas içindeki ATP'ler kullanılır. Daha sonrasında ise egzersizin şiddet ve süresine göre üç enerji sistemi devreye girmektedir. Egzersiz bittikten sonra da organizmadaki enerji tüketimi belirli bir süre daha hızlı bir şekilde devam eder. Egzersiz sonrasında, metabolizmadaki işlevler istirahat düzeyindeki duruma hemen dönememekle beraber egzersiz sonrası toparlanma sürecinde de $\mathrm{O}_{2}$ 'in tüketimi devam eder. (Günay ve Cicioğlu, 2001).

Toparlanma, herhangi bir egzersiz uygulamasından sonra organizmanın fiziksel ve psikolojik açıdan normal durumuna geri dönme süreci olarak tanımlanmaktadır. Kısaca toparlanma, organizmanın egzersiz öncesi değerlere dönmesi olarak kabul edilir (Köseoğlu, 2008). Egzersiz sonrasında toparlanma sürecine önem verilmelidir. Bu süreçte enerji maddelerinin tekrardan sağlanması, metabolik atıkların vücuttan uzaklaştırıması, yorgunluk ve ağrı algısının azaltııması ve/veya giderilmesi, sıvı-elektrolit dengesinin sağlanması gibi egzersiz öncesi değerlere dönmeye yönelik birtakım fonksiyonlar gerçekleşir (Stupnickiet al.,2010). Vücudun kendisini tam olarak toparlayabilmesi, harcanan enerjinin yenilenmesine ve 
Kara, E., Ünver, G. (2019). Masaj ve Toparlanmaya Etkileri. Gaziantep Üniversitesi Spor Bilimleri Dergisi, 4(1), 28-49.

antrenman sırasında biriken laktik asidin uzaklaştırımasına bağlıdır. Dinlenirken tüketilen $\mathrm{O}_{2}$, bu süre içinde tüketilen ATP enerjisinin bir kısmını karşılar. Kasların fosfojen (ATP+PC) intiyacı birkaç dakikada karşılanırken, kasların tam olarak dinlenebilmesi ve karaciğerin glikoz dengesinin kurulması birkaç gün sürebilir. (Fox et al., 2011; Günay ve ark., 2010). Sportif aktiviteler sonrasındaki toparlanma süreci, performansın optimal düzeyde devamlılığı ve performansın kalitesi açısından son derece önemlidir. (Vaile, 2008). Çünkü, toparlanma, sporcunun egzersiz uygulamaları, antrenman ve müsabaka sonrasında, başta enerji rezervlerinin doldurulması ve performansın artmasına yönelik pek çok fizyolojik mekanizmanın gelişmesine imkan sağlayan bir süreçtir (Bıshop, et al., 2008).

Gerek bireysel gerekse takım halinde yapılan sportif aktiviteler, belirli sürelerde gerçekleştirilir. Sporcuların bazı sporlar dallarında yoğun antrenman yapması veya ilgili branşa göre gün içerisinde fazla sayıda müsabakaya katılması gerekebilir. Gün içerisinde üç saatten daha fazla süren antrenmanlar, antrenman yükünün haftada \% 30'dan daha yüksek bir oranda arttırıması, antrenman periyotlamasındaki yanlışlıklar, sporcuların streslerini daha fazla yükseltmekte ve bunu takiben uygun toparlanmaya olan ihtiyacı daha da artırmaktadır (Ahmaidi et al., 1996; Kirkendal, 1990; Bompa ve Gregory, 2009; Alemdaroğlu ve Koz, 2011).

Toparlanmaların genel olarak amacı, organizmayı egzersizden önceki şartlara yeniden hazırlamaktır. Diğer bir deyişle egzersiz sonrası toparlanmanın amacı organizmanın tümüyle antrenman öncesi pozisyona dönmesini sağlamaktır (Tomlin, and Wenger 2001; Fox et al., 2011). Toparlanmanın amaçlarını ayrıntılı olarak şu şekilde sıralayabiliriz: vücut fonksiyonlarının normale dönmesi, homeostatik dengenin normale dönmesi, enerji kaynaklarının yenilenmesi, yorgunluğun ortadan kaldırılması, enzimatik fonksiyonların yeniden normal hale gelmesi.(Bıshop et al., 2008; Eniseler, 2010; Gümüşdağ ve ark. 2015). Egzersiz sırasında enerji kaynağı olarak egzersizin türü, şiddeti ve süresine bağlı olarak ATP, PC, yağlar ve glikojen, enerji kaynağı olarak kullanılmaktadır. Bu yüzden egzersizde, enerji depolarında boşalma meydana gelir. Egzersiz sonrasındaki toparlanma döneminde kastaki ATPPC ve glikojen kaynakları ile birlikte karaciğerdeki glikojen de yenilenmektedir (Günay ve ark., 2010).

Toparlanma süreci, antrenman seansının şiddetine, kullanılan enerji sistemlerine ve antrenmanın amacına bağlıdır. Enerji rezervleri, kasların işlevlerini etkiler ve sahip oldukları özelliklerin bir bölümü ile de (latent zamanı, kapasite, güç, 
Kara, E., Ünver, G. (2019). Masaj ve Toparlanmaya Etkileri. Gaziantep Üniversitesi Spor Bilimleri Dergisi, 4(1), 28-49.

sınırlayıcı etkenler) ATP' nin yenilenmesine olanak sağlarlar (Karatosun, 2010). Doğru bir toparlanma ile uygulama yapılan bölgeye kan akışının hızlanması, kan laktatının uzaklaştııımasının kolaylaşması, ödem ve inflamasyonun azaltılması, genel kan dolaşımının arttırıması, kas sertliğinin azaltıması, eklem hareket açıklığının arttırılması (esnekliğin arttırıması), kuvvet, sürat performansının geri kazanımı, gecikmiş kas ağrısı azaltıımasını sağlanmış olur (Cochrane, 2004).

Antrenman ve toparlanma ilişkisi doğru bir şekilde ayarlanmadığında, sporcuların antrenman ve/veya müsabakalardan belirli bir süre uzak kalması, hatta sporcuların sporu bırakması gibi olumsuz neticeler doğabilir. Tam toparlanma olmadan yapılan yüklenmeler, sporcularda kronik yorgunluğun oluşmasına ve bu durumu takiben yaralanmaların meydana gelmesine yol açabilir (Sılva, 1990). Toparlanma, organizmanın yenilenme hızını artııır, ağıı, kronik yorgunluk ve sakatlanma risklerini en aza indirir. Yüklenme ve uyum sürecinin değerlendirilmesinde, yüklenmenin öğeleri ile dinlenmenin sonucunun beraber değerlendirilmesi önemlidir. Bu anlamda düşünüldüğünde toparlanma ne kadar kaliteli ve kısa sürede yapılırsa, o kadar kaliteli sonuçlar ve yüksek seviyeli başarılar ortaya konulur. Doğru ve uygun toparlanma yönteminin uygulanması, yüklenme ile toparlanma arasındaki dengenin sağlanmasına dair bilincin yerleşmesi ve uygulamaya geçirilmesi hem sporcunun sağlığı hem de optimum performansa ulaşılması açısından oldukça önemlidir (Sevim, 1995).

Toparlanma süreci üzerinde etkili olan birtakım faktörler mevcuttur. Bu faktörler arasında sporcunun genel sağlık durumu, yaşı, cinsiyeti, genetik faktörler, herhangi bir yaralanmasının olup olmaması durumu, sporcunun yaptığı spor branşının özellikleri, sporcunun ihtiyaçları, antrenmanların niceliği, hatalı ve fazla yüklenmeler, beslenme durumu, iklim açısından değişiklikler, çevresel faktörler( irtifa gibi), psikolojik faktörler, uyku kalitesi, yaşam şekli, sosyal ortamın niteliği, jetlak etkisi, zaman intiyacı ve özel toparlanma tekniklerinin kullanılması yer alır (Jemnı et al., 2003). Sporcular için doğru ve organizma için gerekli toparlanmanın sağlanabilmesi amacıyla, toparlanma stratejileri değerlendirilip belirlenmeye çalışılmaktadır (Bompa, ve Gregory 2009).

\section{Toparlanma Stratejileri}

Toparlanmanın başarıı olması için, en uygun toparlama stratejisini uygulamaya geçirmek önemlidir. Uygun toparlanma stratejisini belirlerken de intiyaçlar ve oluşmuş olan biyokimyasal, mekanik, fizyolojik değişiklikler kapsamında 
Kara, E., Ünver, G. (2019). Masaj ve Toparlanmaya Etkileri. Gaziantep Üniversitesi Spor Bilimleri Dergisi, $4(1), 28-49$.

değerlendirme yapılmalıdır (Eniseler, 2010). Yapılan çalışmalar incelendiğinde, toparlanmada etkili olan stratejilerin arasında, şu yöntemlerin olduğu görülmektedir: hidroterapi (CWI,HWI,CWT), aktif toparlanma (genellikle düşük şiddette aerobik koşu), stretching (germe), masaj uygulamaları, farmakolojik yaklaşımlar (analjezik ve antiinflamatuarlar), uygun beslenme, yeterli sıvı alımı, ergojenik yardımcıların kullanımı, elektrostimulasyon (TENS, ultrason v.b.), hiperbarik oksijen terapisi, psikolojik terapiler, yaşam tarzı modifikasyonları ve bunların bazılarının bir araya getirilerek beraber uygulandıkları kombine yöntemler (Tessıtore et al., 2007).

\section{Toparlanmada Bir Strateji Olarak Masaj ve Masajın Toparlanmaya Dair Etkilerinin Aktarıldığı Çalışmalar}

Toparlanma stratejileri arasında yaygın olarak kullanılan stratejilerden birisi de masajdır. Masajın kan akımını arttırması, toparlanma adına en genel ana mekanizma olarak değerlendirilmektedir. Masajın, egzersiz sonrası toparlanmanın düzeyine etkisi veya zamansal açıdan fizyolojik etkisi tam olarak bilinmemesine rağmen, en fazla ileri sürülen etki mekanizması, kas kan akımını arttırması olmuştur. Kan akışının artmasıyla fiziksel, fizyolojik ve psikolojik etkiler görülmektedir. Kan akışının artışı, temelde metabolik atık ürünlerinin temizlenmesi, dokuya oksijen iletiminin artması, dokularda sıvı değişiminin hızlanması, dokulara daha fazla besin maddesinin alınımı gibi homeostazinin sağlanması için pek çok fizyolojik olayın gerçekleşmesine yardım ederek, vücudun istirahat halindeki değerlere dönmesi sağlanmış olacaktır. Dolayısıyla iyileşmenin hızlanması sağlanacak ve performansın yükselmesine yönelik etkiler oluşacaktır.

Masajın izole olarak uygulanması ya da diğer toparlanma stratejileriyle kombine edilerek uygulanmasına dair çalışmalar incelendiğinde; bazılarında masajın etkili olduğu görülürken, bazı çalışmalarda ise hiç etkisinin olmadığına dair bilgiler elde edilmiştir.

Baydil ve ark.'In total olarak uygulanan klasik masajın egzersiz sonrası toparlanmaya etkisini belirlemek amacı ile yaptıkları çalışmalarında, yorucu egzersizlerden sonra toparlanma amacıyla uygulanan masajın ve pasif dinlenmenin farkını karşılaştırmışlardır. Bu karşılaştırmada, bir toparlanma stratejisi olarak uygulanılan masajın laktik asidin uzaklaştırılmasında pasif dinlenmeye oranla daha etkili bir yöntem olduğu belirtilmiştir (Baydil ve ark., 2017).

Lane ve Wanger, bisiklet performansı üzerine masajın etkisinin, pasif toparlanmaya oranla daha iyi olduğunu rapor etmişlerdir. Aktif toparlanma ve soğuk 
Kara, E., Ünver, G. (2019). Masaj ve Toparlanmaya Etkileri. Gaziantep Üniversitesi Spor Bilimleri Dergisi, 4(1), 28-49.

suya daldırmanın (CWI) ise masaja kıyasla daha fazla fayda sağladığını da belirtmişlerdir (Lane and Wanger, 2004).

Cochrane'nin çalışmalarında; aktif toparlanma ile masajın kombine edilmesiyle yapılan 20 dakikalık toparlanma sürecinin, 5 dakikalık performansı sürdürmede pasif, aktif ve masaj toparlanma yöntemlerinden daha etkili olduğunu aktarmışlardır. Yine laktik asidin uzaklaştırılmasına dair etkisi en fazla olan yöntemler arasında yer alan yöntem aktif toparlanma iken, yapılan kombine yöntemin 3. dakika itibariyle pasif toparlanmadan, 15.dakika itibariyle ise tüm yöntemlerden daha etkili olduğu da belirtilmiştir (Cochrane, 2004).

Monedero ve Donne, $5 \mathrm{~km}$ 'lik bisiklet antrenmanı ile çalışan sporcularda aktif bisiklet ve masajdan oluşan kombine bir toparlanmanın, izole olarak uygulanan bisiklet, masaj ve pasif iyileşme stratejileri ile mukayese edildiği çalışmalarında, kombine uygulanan yöntemin, performansı korumada daha etkili olduğunu göstermişlerdir. Bu çalışma, masajın diğer toparlanma yöntemleriyle beraber uygulandığında, daha etkili olabileceğini vurgulamaktadır (Monedero and Donne, 2000).

Robertson ve arkadaşları, 30 sporcu üzerinde çalışma yapmışlardır. Çalışmaları kapsamındaki 30 sporcuyu, öncesinde 30 sn'lik wingate testi, ardından 30 sn'lik bir dinlenme ve $20 \mathrm{dk}$ 'lık bir masaj uygulaması yaparak incelemeye almışlardır. Bulgularda kan laktat oranı açısından hiçbir değişiklik olmadığını, yorgunluk indeksi açısından \% 34'den, \% 30'a doğru gelişen oransal bir iyileşmenin görüldüğünü rapor etmişlerdir. Bu çalışma bize bir toparlanma stratejisi olan masajın, yorgunluk indeksi üzerine olumlu etkisi olduğunu göstermiştir (Robertson et al., 2004). Bu çalışmanın sonuçlarıyla benzer şekilde, masajın, yorgunluk indeksi, yapılan toplam iş gibi performans değerlerinde, olumlu etkiye sahip olduklarını Lane ve Wenger yaptıkları çalışmalarında aktarmışlardır (Lane and Wenger, 2004).

Genellikle, eksantrik kasılma içeren egzersizler sonrası görülebilen, gecikmiş kas ağrısı, toparlanma sürecinde hem sporcular hem de antrenörler için önemli sorunlardan biridir. Gecikmiş kas ağrısı, sporcularda kas fonksiyonlarının azalmasına, kronik ağrıya ve sportif açıdan yeteneğin zayıflamasına neden olmaktadır. Ernst ile Smith ve ark. 'ın yapmış oldukları çalışmalarında, masaj uygulamalarının gecikmiş kas ağrısında önemli derecede azalma sağladığını göstermişlerdir (Ernst, 1998; Smith et al., 1994). 
Kara, E., Ünver, G. (2019). Masaj ve Toparlanmaya Etkileri. Gaziantep Üniversitesi Spor Bilimleri Dergisi, $4(1), 28-49$.

Sarı ve ark. çalışmalarında, toparlanma yöntemlerinden aktif dinlenme ve masajın yüklenme öncesi, yüklenme sonrası, 5. dakika, 10. dakika ve 20. dakika ölçümlerinde, grup içi karşılaştırmalara yer vermişlerdir. Toparlanma yöntemi olarak, masaj uygulaması aktif dinlenme yöntemine göre, kan laktik asitinin uzaklaştırılması ve kalp atım sayısının düşmesi açısından daha etkili olmuştur. Bu durumun, masaj uygulamasının kan dolaşımını pasif şekilde artırarak, kan laktatının hızla uzaklaşmasını sağlamasından kaynaklanabileceğini belirtmişlerdir. Öte yandan bu çalışmada farkı toparlanma yöntemleri arasında istatistiksel olarak anlamlı fark olmamasına rağmen, toparlanma süresi açısından, masaj ile toparlanmanın, aktif toparlanmaya göre daha etkili olduğu görülmüştür (Sarı ve ark., 2016).

Kaya, bir çalışmasında masaj ve pasif dinlenmenin kombine bir şekilde uygulamasını yapmıştır. Bu uygulama neticesinde, kan laktik asit düzeyinin, normal düzeyine dönüş eğiliminde olduğunu belirlemiştir (Kaya, 1994).

Dubrovsky, alt ve üst ekstremitelere 15-25 dakika kadar süreyle masaj yaparak toplardamarlardaki kan akımını tespit etmiş ve sonuçta masajın yüzeysel damarları dilate ederek venlerde önemli derecede kan akışını hızlandırdığını, bu durumun toparlanmaya olumlu yönde etki gösterdiğini belirtmiştir (Dubrovsky, 1983).

Bırukov ve Pocıosyan yaptıkları çalışmada; el masajı, su altı masajı ve gevşeme egzersizleri gibi toparlanma metotlarının güreşçilerde daha çabuk toparlanmayı sağladığını belirtmişlerdir (Bırukov ve Pocıosyan, 1984).

Öztürk, çalışmasında, müsabaka sonunda hentbolculardan oluşan iki gruptan birine 30 dakika pasif dinlenme ve diğer gruba 30 dakika masaj uygulayarak, elde edilen sonuçları karşılaştırmışı̧ı. Karşılaştırma sonucunda, grupların kendi içinde müsabaka öncesi ve müsabaka sonrası değerlerinde, anlamlı farklılık bulunurken, grupların arasında herhangi bir anlamlı farklılığa rastlanmamıştır (Öztürk, 2008).

Yapılan tüm çalışmalar değerlendirildiğinde, masajın toparlanmada olumlu etkisini savunan sonuçlar mevcutken, masajın toparlanma üzerine az ya da hiçbir etkisinin olmadığını vurgulayan sonuçlar da mevcuttur.

Wiltshire ve arkadaşları, çalışmalarında masajın kan akışını ve laktatın uzaklaştırımasını azalttığını ve engellediğini bildirmişlerdir. Zira bu çalışmada, masajın kasa baskı uygulaması sebebiyle, mekanik olarak kan akımını engelleyici bir etki ortaya çıkardığı; bunun da kandan laktik asidin uzaklaştırmasını yavaşlattığı aktarılmıştır. (Wiltshire et al., 2010). 
Kara, E., Ünver, G. (2019). Masaj ve Toparlanmaya Etkileri. Gaziantep Üniversitesi Spor Bilimleri Dergisi, 4(1), 28-49.

Monedero ve Donne ile Tiidus ve Shoemaker çalışmalarında masaj esnasında kan akışında ve laktatın uzaklaştırılmasında artış olmadığını göstermişlerdir. Monedero ve Donne, bisiklet performansı üzerinde masajın pasif dinlenmeden etkili olmadığını rapor etmişlerdir (Monedero and Donne, 2000; Tiidus and Shoemaker, 1995).

Ayrıca Tiidus ve Shoemaker, Doppler ultrason ve Xenon ile yıkama tekniği kullanılarak yapılan çalışmalarında, egzersiz öncesi ve sonrası yapılan masajın, kan akımını artırmaya yönelik herhangi bir anlamlı etkisinin olmadığını aktarmışlardır (Tiidus and Shoemaker, 1995).

Barnett ile Weerapong ve arkadaşları, masaja yönelik çalışmalardaki bazı kanıtların, masajın toparlanmada psikolojik yönden yararları olduğunu belirtirken, çoğu kanıtın, toparlanmayı artırmada ya da performans faydaları sağlamada bir yöntem olarak masajı desteklemediğini belirtmişlerdir. (Barnett, 2006; Weerapong, 2005).

Masajın, toparlanma çalışmalarında kullanılma nedenlerinden birisi de, laktatın uzaklaştırımasını hızlandırdığına yönelik iddialardır. Laktat oluşumu ile birlikte, PH değerinde düşme olur, $\mathrm{PH}$ değerinin azalmasıyla fosfofruktokinaz enziminin inhibisyonu görülür ve glikoliz yavaşlaması olur, enerji veren maddelerin azalmasıyla da kaslarda kontraksiyonlar kısıtlanır. Hem kas içinde biriken hem de kanda biriken laktat, yorgunluğa neden olur. Bangsbo ve arkadaşları, çalışmalarında, masajın yorgunluğa neden olan laktik asit eleminasyonu üzerinde, anlamlı bir etkisinin olmadığını göstermişlerdir (Bangsbo et al., 1994; Gümüşdağ ve ark. 2015).

Gupta ve arkadaşlarının yaptıkları çalışmada, kan laktatının yarılanma süresinin aktif dinlenmede (VO2max'ın \% 30'u) $15.7 \pm 2.5 \mathrm{dk}$, oturur pozisyondaki pasif dinlenmede $21.5 \pm 2.8 \mathrm{dk}$ ve kısa süreli bacak masajında $21.8 \pm 3.5 \mathrm{dk}$ olduğunu ve bunlar arasında aktif dinlenmenin daha etkili olduğunu, yani masajın etkisinin çok fazla olmadığını belirtmişlerdir (Gupta et al., 1996).

Balke ve arkadaşları tarafından yapılan bir çalışmada uygulanan masaj tekniklerinin, kalp atım sayısı ve kan basıncı üzerinde azaltıcı etkileri olduğu tespit edilmiş fakat Boone ve arkadaşları ile Hemmings tarafından yapılan çalışmalarda ise anlamlı sonuçlar tespit edilmemiştir (Balke et al., 1989, Boone et al.,1991, Hemmings, 2000).

Longworth, masajın kan basıncı üzerinde anlamlı sonuçlar ortaya çıkarmadığını belirtmiştir (Longworth, 1982). 
Kara, E., Ünver, G. (2019). Masaj ve Toparlanmaya Etkileri. Gaziantep Üniversitesi Spor Bilimleri Dergisi, 4(1), 28-49.

Bale ve James ile Weerapong ve arkadaşlarının literatürde yer alan çalışmalarda, masaj uygulamasından 12 saat sonra, kan laktatının anlamlı bir seviyede azaldığının tespit edildiğini belirtirlerken (Bale and James, 1991, Weerapong et al., 2005), Gupta et. al., Dolgener ve Morien, Hinds et. al., Hemmings, Ce et al., Pınar ve ark., Robertson ve arkadaşlarının çalışmaları da, egzersiz sonrası masajın, laktat seviyesinin azaltılması üzerine herhangi bir etkisi olmadığı yönündedir (Gupta et al., 1996; Dolgener and Morien 1993; Hinds et. al., 2004; Hemmings,2000; Ce et. al., 2013; Pınar ve ark., 2012; Robertson et al.,2004).

\section{Tartışma ve Sonuç}

Masaj, sağlığı koruyucu ve geliştirici çeşitli manipülatif teknikleri içeren uygulamalardır. Organizmaya, fiziksel, fizyolojik, ruhsal ve sosyal yönden pek çok etkileri mevcuttur. Masaj uygulamalarının çeşitleri olup, bunların arasında en yaygın olarak kullanılan ise İsveç Masajı olarak da bilinen Klasik Masaj'dır. Klasik Masaj'ın da kendi içinde teknikleri bulunmaktadır. Egzersiz uygulamalarıyla da, organizmada değişiklikler olabilmektedir. Bunlar arasında yer alanlardan başlıcaları; enerji kaynaklarında tükenme, hücre içi ve dışı sıvı bileşiminde değişme- artma/azalma (kimyasal, fiziksel, elektriksel), metabolik atıklarda artış, oksidatif streste artış, önemli transmitterlerde azalma, mental ve sinirsel yorgunluk, vücut ısısında artış, doku hasarıdır.

Masaj, sporda toparlanma stratejileri arasında yaygın olarak kullanılan yöntemlerden de birisidir. Toparlanma, antrenman ve müsabakalardan sonra, istirahat halindeki değerleri yakalayabilme sürecidir. Uygun toparlanma tekniğinin seçilmesi ve doğru bir şekilde uygulanması son derece önemlidir. Toparlanmadaki başarı, egzersiz sonrası optimal performansın sağlanabilmesiyle doğrudan ilişkilidir. Toparlanmada esas amaç ise homeostazisi tekrar sağlamaktır.

Masaj uygulamalarının toparlanma üzerine olan etkilerini inceleyen çalışmalar değerlendirildiğinde ise farkı düşüncelerin mevcut olduğu görülmektedir. Toparlanmada, masajın çeşitli parametreler üzerinde etkili olduğu savunulmaktadır. Masajın toparlanmadaki parametreleri etkileyen ana mekanizmasının, kan ve lenf dolaşımını arttırmasından kaynaklı olduğu düşünülmektedir. Kan dolaşımının artışıla da, laktatın uzaklaştıııması, ağııın ve yorgunluğun azaltııması gibi dolaylı etkilerin elde edilişi savunulmaktadır. Bu yöndeki çalışmalar mevcutken, bu etkilerin olmadığı, hatta ilgili etkileri baskıladığına dair çalışmalar da bulunmaktadır. Bu anlamda; 
Kara, E., Ünver, G. (2019). Masaj ve Toparlanmaya Etkileri. Gaziantep Üniversitesi Spor Bilimleri Dergisi, 4(1), 28-49.

masajın toparlanmaya olan etkilerinin değerlendirildiği çalışmaların sayısının artışına intiyaç duyulmaktadır. Bundan sonraki çalışmalarda farklı spor branşlarında, farklı irtifa ve çevresel koşullarda, daha geniş katıımcıların dahil edilebildiği, gerek fiziksel performans göstergeleri (sprint, tekrarlı sprint, çeviklik becerileri, sıçrama, maksimal istemli kasılma kuvveti, esneklik, aerobik performans, teknik beceriler); gerek biyokimyasal parametreler (CK, myoglobin, II-6, CRP, ürik asit-oksitadif stres markırı, kortizol, testosteron) gerekse bilişsel fonksiyonlar (reaksiyon zamanı, karar verme hızı, görsel algı hızı, uzaysal farkındalık ve sezgi gibi) üzerine etkileri araştııılabilir.

\section{Kaynaklar}

Alemdaroğlu U. Koz M. (2011). Egzersiz sonrası Toparlanma: Toparlanma çeşitleri ve yöntemleri, Türkiye Klinikleri J Sports Sci;3(1).

Ahmaidi S. Et. al. (1996). Effects of active recovery on plasma lactate and anaerobic power following repeated intensive exercise. Med Sci Sports Exerc; 28:450-6.

Aourell M. Skoog M. Carleson J. (2005). Swedish massage. Complementary therapies in clinical practise.; 11: 242-246.

Atchison JW. Stoll S. Gllear WG. (1996). Manipulation, traction and massage In: Braddom RL Editor. Physical Medicine And Rehabilitation. Philadelphia: WB saunders company.

Bale P, James H.(1991). Massage, Warmdown and Rest as Recuperative Measures after Short Term Intense Exercise, ,Physiother Sport, 13, 4-7.

Balke B, Anthony J, Wyatt F. (1989). The Effects of Massage Treatment on Exercise Fatigue,, Clin Sports Med, 1, 189-96.

Bangsbo J, Graham T, Johansen L, Saltin B. (1994). Muscle lactate metabolism in recovery from intense exhaustive exercise: impact of light exercise. J Appl Physiol;77(4):1890-5.

Barnett, A. (2006). Using recovery modalities between training sessions in elite athletes: does it help? Sports Med. 36: 781-796.

Baydil B, Gürses VV, Koç MC. (2017). Masajın bazı toparlanma parametrelerine etkisi, Sportif Bakış: Spor ve Eğitim Bilimleri Dergisi, SI (1), 63-69.

Beyazova, M. Kutsal, Y.G. (2000). Fiziksel Tıp ve Rehabilitasyon Cilt 1, Güneş Kitabevi, s:849,850. 
Kara, E., Ünver, G. (2019). Masaj ve Toparlanmaya Etkileri. Gaziantep Üniversitesi Spor Bilimleri Dergisi, 4(1), 28-49.

Bırukov A, Pocıosyan M.(1984).Special Means ofRes- toration of Work Capacity of Wrestlers in the Periods Between Competitive Bouts, (Con- donsed), Sovied Sports Review, Vol. 19, No: 4, 191-192.

Bıshop AP, Eric J, Krista W. (2008). Recovery from training: a brief review. J Strenght Cond Res,; 22(3):1015-24.

Blanc-Louvry et. al. (2002). Does mechanical massage of the abdominal wall after colectomy reduce postoperative pain and shorten the duration of ileus?, ,Journal of Gastrointest Surgery,. 6: 43-49.

Bompa TO. Gregory H. (2009). Rest and recovery. In: Bahrke MS, Ewing S, eds. Periodization: Theoryand Methodology of Training. 5th ed.Leeds: Human Kinetics Publishers; p.99-107.

Boone T. Cooper R, Thompson WR. (1991). A Physiological Evaluation of Sports Massage,, Athletic Training, 26, 51-4.

Ce E, Limonta E, Maggioni MA, Rampichini S, Veicsteinas A, Esposito F. (2013). Stretching and Deep and Superficial Massage do not Influence Blood Lactate Levels after Heavy-intensity Cycle Exercise, J Sports Sci., 31(8), 856-66.

Cochrane DJ. (2004). Alternating hot and cold water immersion for athlete recovery. A review. Physical Therapy in Sport.;67: 26-32.

Day JA. Mason RR. Ceshrown SE. (1987). Effecty of massage on serum level of $B$ endorfin and B lipotropin in healty adults. Physical Therapy,; 67(6): 926-930.

Demir SG. (2008). Meme kanseri nedeniyle ameliyat olan hastalarda kendi kendine lenfödem yönetimi. Gazi üniversitesi, Hemşirelik yüksekokulu, Ankara, Türkiye.

Dicle A. (2007). Cerrahi Hastasında Ağrı. Akbayrak, N. ve ark. (Ed.). Hemşirelik Bakım Planları Kitabı,Ankara:Alter Yayıncılık.

Dolgener F, Morien A. (1993). The Effect of Massage on Lactate Disappearance, J Strength Cond Res., 7(3), 159-62.

Dubrovsky VI. Changes in Muscle and Venous Blood Flow After Massage (9/1983); Soviet Sports Review, Vol. 18, No: 3, 134-135.

Edmond SL. (2006). Joint Mobilization/Manipulation Extremityand Spinal Tecniques. 2nd ed., New York: Mosby.

Eniseler N. (2010). Bilimin Işığında Futbol Antrenmanı. 1. Baskı. İzmir: Birleşik Matbaacılık, 334-54. 
Kara, E., Ünver, G. (2019). Masaj ve Toparlanmaya Etkileri. Gaziantep Üniversitesi Spor Bilimleri Dergisi, 4(1), 28-49.

Ernst E. (1998). Does post-exercise massage treatment reduce delayed onset muscle soreness?

Ernst E. (1999). Massage therapy for low back pain: a systematic review. J. Pain Symptom Manag., 17: 65-9. 92.

Fernández-de-Las-Peñas $\quad$ C, Alonso-Blanco $\quad C$, Cuadrado $\quad M L$, Miangolarra JC, Barriga FJ, Pareja JA. (2006). Are manual therapies effective in reducing pain from tension-type headache?, A systematic review. Clin J Pain.; 22(3):278-285.

Field T. (2000). Massage Therapy, Touchpoints.; 7(1): 1-3.

Fox EL, Bowers RW, Foss ML. (2011). Beden Eğitimi ve Sporun Fizyolojik Temelleri. 3.Baskı. Ankara: Spor Yayınevi ve Kitabevi,; 31-49.

Fritz S. (1995). Mosby's Fundamentals of Therapeutic Massage., Mosby-Year Books, St. Louis: Inc.

Gupta G. Goswami A. Sadhukhan AK. Mathar DN.(1996). Comparative study of lactate removal in short term massage of extremities, active recovery and a passive recovery period After supramaximal exercise sessions, Int J Sports Med 17:106-10.

Gümüşdağ H. Egesoy H, Cerit E. (2015). Sporda Toparlanma Stratejileri, Hitit Üniversitesi Sosyal Bilimler Enstitüsü Dergisi, yıl 8, sayı 1, s:53-69.

Günay M. Tamer K. Cicioğlu G. (2010). Spor Fizyolojisi ve Performans Ölçümü. 2. Baskı. Ankara: Gazi Kitabevi,; 80-85, 126-27.

Günay M., Cicioğlu G. (2001). Spor Fizyolojisi. 1. Baskı. Ankara: Gazi Kitabevi,; 7587.

Harbili E. (1998). Yoğun Egzersizden Sonra Aktif Dinlenmenin Laktik Asit Eliminasyonuna Etkisi, Yüksek Lisans Tezi, Selçuk Üniversitesi, Konya.

Hazır M. (2001). Spor Masajı Teori ve Uygulama, Ankara:Bağırgan Yayınevi, s:2736.

Hemmings B. (2000). Psychological and Immunological Effects of Massage after Sport, Br J Ther Rehabil., 7(12), 516-19.

Hinds T, McEwan I, Perkes J, Dawson E, Ball D, George K. (2004). Effects of Massage on Limband Skin Blood Flow after Quadriceps Exercise, Med Sci Sports Exerc., 36(8), 1308-13. 
Kara, E., Ünver, G. (2019). Masaj ve Toparlanmaya Etkileri. Gaziantep Üniversitesi Spor Bilimleri Dergisi, 4(1), 28-49.

Jemnı M, Sands WA, Friemel F, Delamarche P. (2003). Effect of active and passive recovery on blood lactate and performance during simulated competition in high level gymnasts., Can J Appl Physiol;28(2):240-56.

Jiang PS, Qin Y. (2008). Touch therapies for pain relief in adults. Cochrane Database Syst Rev.; 8(4): 1-45

Kanbir O. (1998). Klasik Masaj, Bursa:Ekin Kitabevi Yayınları.

Kanbir O. (2008). Klasik Masaj Dinlendirme, Tedavi, Spor Masajı, Bursa:Ekin Basım Yayın Dağıtım.

Karadeniz G. (1997). Hastanızın ağrısını ilaç kullanmadan nasıl azaltabilirsiniz hemşireler ve öğrenci hemşireler için rehber kitapçık, Manisa: Emek Matbaacılık.

Karatosun H. (2010). Antrenmanın Fizyolojik Temelleri. 3. Baskı. Isparta: Altıntuğ Matbaası, 137-49.

Kaya M. (1994). Masajın Egzersiz Sonrası Toparlanmaya Etkisi, G.Ü. Sağlık Bilimleri Enstitüsü Beden Eğitimi ve Spor Anabilim Dalı, Doktora Tezi.

Kirkendal DT. (1990). Mechanism of Peripheral Fatique. Med. and sci, in Sports and Exercise, Vol. 22, No: 4, U. S. A. , $444-449$.

Kolcaba K., Schirm V, Steiner R. (2006). Effects of hand massage on comfort of nursing home residents., Geriatric Nursing, 27(2): 85-91.

Köseoğlu A, Kin A. (2008). Supramaksimal bir bacak egzersizi sonrası farklı sürelerde uygulanan bacak masajının toparlanmaya etkisi. 10.Uluslararası Spor Bilimleri Kongresi Özet Kitabı, , p. 49.

Kurre O. (1997). Massage and the Original Swedish Movements, Virginia University of Virginia Library.; s:7-12.

Kwekkeboom KL. Gretarsdottir E. (2006). Systematic review of relaxation Interventions for pain. Journal of Nursing Scholarship; 38: 3, 269-277.

Lane, K.N., and H.A. Wenger (2004). Effect of selected recovery conditions on performance of repeated bouts of intermittent cycling separated by 24 hours. J. Strength Cond. Res. 18: 855-860.

Lindrea KB, Stainton MC. (2000). Infant Massage Outcomes. The American Journal of Maternal Child Nursing.; 25(2): 95-99.

Longworth JCD. (1982). Psychophysiological Effects of Slow Stroke Back Massage on Normotensive Females, , Advan Nurs Sci., 50, 44-61. 
Kara, E., Ünver, G. (2019). Masaj ve Toparlanmaya Etkileri. Gaziantep Üniversitesi Spor Bilimleri Dergisi, 4(1), 28-49.

Melzack R. Wall PD. (1996). The Challenge of Pain, 2nd ed., London: Penguin Books.

Monedero, J., and B. Donne (2000). Effect of recovery interventions on lactate removal and subsequent performance. Int. J. Sports Med. 21: 593-597.

Monedero, J., and B. Donne (2000). Effect of recovery interventions on lactate removal and subsequent performance. Int. J. Sports Med. 21: 593-597.

Myers CD, Walton T, Bratsman L, Wilson J, Small B. (2008). Massage modalities and symptoms reported by cancer patients: Narrative review., Journal of the Society for Integrative Oncology, Vol 6, No 1 (Winter), 2008: pp 19-28.

Öztürk M. (2008). Edirne Büyük Erkekler Hentbol Ligine Katılan Takımların Müsabaka Öncesi ve Sonrası Laktik Asit Düzeylerinin Belirlenmesi ve Masaj Uygulamasının Olası Etkilerinin Araştırıması, Yüksek Lisans Tezi..

Pınar S, Kaya F, Biçer B, Erzeybek MS, Çotuk HB. (2012). Different Recovery Methods and Muscle Performance after Exhausting Exercise: Comparison of the Effects of Electrical Muscle Stimulation and Massage, Biology of Sport, 29(4), 269-75.

Reed BV. Held J M. (1988). Effects of sequential connective tissue massage on autonomic nervous system of middle-aged and elderly adults., Phys Ther, 68 (8), 1231-1234.

Robertson A. Watt JM. Galloway SDR. (2004). Effects of Leg Massage on Recovery from High Intensity Cycling Exercise, Br J Sports Med., 38, 173-6.

Sarı R, Demirkan E, Kaya M. (2016). Farklı toparlanma uygulamalarının yüzücülerde laktik asit düzeyine etkisinin incelenmesi, Journal of Contemporary Medicine;6(4): 327-333.

Sarıkaya S. (2002). Annelerin uyguladığı masajın prematüre ve düşük doğum ağırıkı bebeklerin büyüme-gelişmesine etkisi, Dokuz Eylül Üniversitesi, İzmir:Sağlık Bilimleri Enstitüsü, Yükseklisans Tezi.

Sevim Y. (1995). Antrenman Bilgisi. 5. Baskı. Ankara, Gazi Büro Kitabevi,132-33.

Sılva JM. (1990). An analysis of the training stress syndrome in competitive athletics., J Applied Sport Psychol;2(1):5-20.

Smith LL, Keating MN, Holbert D, Spratt DJ, McCammon MR, Smith SS, Israel RG. (1994). The effects of athlete massage on delayed onset muscle soreness, creatine kinase and neutropil count: A preliminary report. J Orthop Sports Physther;19(2):93-9. 
Kara, E., Ünver, G. (2019). Masaj ve Toparlanmaya Etkileri. Gaziantep Üniversitesi Spor Bilimleri Dergisi, 4(1), 28-49.

Stupnicki R, Gabrys T, Szmatlan UG, Tomaszewski P. (2010). Fitting a single-phase model to the post-exercise changes in heart rate and oxygen uptake. Physiological Research,. 59, 357- 362.

Tessitore A, Meeusen R, Cortis C, Capranica L. (2007). Effects of different recovery interventions on anaerobic performances following preseason soccer training. J.Stretigfh Cond.; Res;21(3):745-50.

Tiidus PM. Shoemaker JK. (1995). Effleurage massage, muscle blood flow and long term postexercise recovery. Int J Sports Med;16(7):478-83.

Tomlin DL, Wenger HA. (2001). The relationship between aerobic fitness and recovery from high intensity intermittent exercise. Sport Medicine, 31: (1), 111.

Torsten T.A. (1997). The Physical Therapy Approach. In: Frymoyer JM. (ed): The Adult Spine: Principles and Practice, 2nd edPhiledelphia: Lippincot-Raven Publishers, 1797-1804. 93.

Touch Research Institute. (2009). Touch Research Institute Studies.

Tuna N. (1997). A'dan Z'ye Masaj. Ankara:Nobel Tıp Kitabevi.

Uzuner YY. (1998). Dokunmanın önemi. Hemşirelik forumu.; 1(6): 245-255.

Vaile J, (2008). Effect of hydrotherapy on recovery of muscle-damage and exerciseinduced fatigue. European Journal of Applied Physiology.;11: 69-72

Weerapong P, Hume PA, Kolt GS. (2005). The Mechanisms of Massage and Effects on Performance, Muscle Recovery and Injury Prevention, Sports Med., 35(3), 235-56.

Wilmore J. Costill D. (1994). Physiology of sport and exercise. Champaign, IL: Human Kinetics.

Wiltshire EV, Poitras V, Pak M, Hong T, Rayner J, Tschakovsky ME. (2010). Massage impairs postexercise muscle blood flow and "lactic acid" removal. Med. Sci. Sports Exerc. 42: 1062-1071.

Yates, J. A.(2004). Physician's Guide to Therapeutic massage, (3rd ed): Toronto: Curties Overzet Yayımevi.

Yı H, Fan L, Yang X, Chen Y. (2008) Effect of Rolling Massage on Particle Moving Behaviour in Blood Vessels Chın, Phys.Lett.,; Vol. 25, No.9-3496.

Yüksel İ. (2007). Masaj Teknikleri, Ankara: Alp Yayınevi. 